\title{
A Lower Permian Fauna from North Manchuria
}

\author{
By \\ Mitsuo NoDA* \\ (Received: Nov. 7, 1950) \\ Introduction
}

Some years ago, the author received from Sigemitsu OKADA, a geologist of the former Geological Institute of Manchoukuo at Changchun, Manchuria, a series of Permian invertebrate fossils which he obtained at Hsiehshao," about $8 \mathrm{~km}$ south of the Yuchuan ${ }^{2)}$ station, formerly the Erhtsengtientzus station, on the HarbinSuifenho line.)

According to OKADA, the Permian complex of this district is very irregularly distributed in small and detached areas. Although its base is unknown, it consists chiefly of gray fossiliferous sandstones and black slates, which, in places, are so metamorphosed as to be called hornfels. Thin limestones are intercalated in the lower and the upper parts. The rock which yie'ded the fossils at Hsiehshao is a non-calcareous, greenish gray massive sandstone. The whole complex strikes west to sijghtly north, with a dip $80^{\circ}$ to southwest or vertical, and is intruded by granite of unkown age. The Permian formations and the granite are covered by various volcanic rociks such as liparite, porphyrite, porphyry, ete.

The fossils are largely fragmentary and much crushed, but a few are well enough preserved to permit identification. The following is a list of the remains which have been recognized.

Brachiopoda

1: Spirifer moosaknailensis DAVIDSON

2. Waagenoconcha cf. purdoni (DAVIDSON)

3. Linoproductus cora (d'ORBIGNY)

Pe'ecypoda

4. Pseudomonotis (Aviculomonotis) kazanensis (de VERNEUIL)

Undeterminable crinoid-stem joints are also obtained.

The fauna, although meager, has an undoubted Lower Permian aspect, the best preserved and accurately identified forms occurring in other marine Permian deposits of Greater East Asia.

The name, Erhtsengtientzu, is in fact very familier to us, because of the many

* Geological Institute, 2nd Branch of Kyushu University, Kurume.

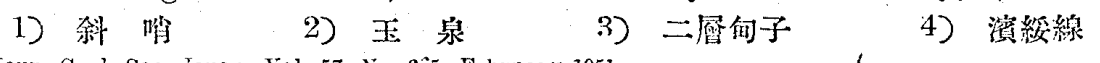

Jour. Geul. Soc. rapan, Vol. 57, No. 6:5, Febraty 1951. 
Permo-Carboniferous fossils reported over twenty years ago by AHNER $T^{5)}$ from the limestone there. The important fossils listed by him include the following Brachiopoda: Productus cf. boliviensis d'Orb., P. weyprechti Toul., P. mammatiformis FRED., P. aculeatus MART., P. waageni RoTHP., P. purdoni DAVID., Paramarginifera peregrina FRED., Spirifer striatus mut. neostriatus FRED., Spriferella rajah (SALT.), S. lytha FRED. and S. ef. vercherei WAAG. AHNERT also lists the following: Polypora sykeri WAAG. (a Bryozoa); Aviculopecten cf. subclathratus KEYs. (a Pelecypoda); and Berellophon sp. (a Gastropoda).

According to OKADA, many fossils are also preserved in the limestone of the upper part of the complex of Hsiehshao, which may correspond to the limestone of Yuchuan containing the above fossils reported by AHNERT.

The author is grateful to OKADA for his courtesy in contributing these fossils.

\section{Notes on the Species}

Brachiopoda

\section{Order Telotremata BEECHER, Family Spiriferidae KING Genus Spirifer SOWERBY \\ Spirifer moosakhailensis DAVIDSON \\ Pl. 1 Figs. 1-4}

1862. Spirifer moosakhailensis, Davrdson, Quart. Jour. Geol. Soc. London, Vol. XVI11, p. 28, Pl. II, Fig. 2.

1892. Spirifer musakheylensis, Ronнrürz, Paläontographica, Bd. XXXIX, p. 79, Pl. IX, Figs. 1, 2.

1911. Spirifer musakheylensis, F

1913. Spirifer musakheylensis, Mavisư, Mém. Sér. vice Géol., Indochine, Vol. II, Fasc. 4, p. 57, pl. V, Fig. 6.

1916. Spirifer fasciger, BroILI, Paläontologie von Timor, Lief. VII, p. 37, Pl. CXX, Figs. 11-13; PI. CXXI, Figs. 1-3.

1931. Spirifer moosakhailensis, GraBaU, The Permian of Mongolia, Nat. Hist. Cent. Asia, Vol. IV, p. 168, Pl. XXIII, Figs. 5a-c.

This species is represented by two fragmental moulds of dorsal and ventral valves among our specimens. There is no doubt that it is identifiable with the above species by its characteristic surface sculpture.

The specimens are medium sized, much broader than high, with moderately influted shell. The greatest width of the shell is along the hinge line. The surface of the shell is marked

5) E. Ahnert: Morphologische und Geotektonische Skizze des Russischen Fernen Ostens und Nord Manchuriens; Proc. 3rd Pan. Pac. Sci. Congr. Tokyo, Vo]. I, 1928. 
by numerous radiating plicae which are disposed into three or four bundles near the margin. The plicae though being of very different strength, are always more or less distinctly rounded on their tops, and are never sharp. The fine, concentric, closely disposed lines of growth cover both valves, as its most characteristic feature.

This species closely resembles Spirifer fasciger KEYsERLING which some palaeontologists recognize as a synonym of DAVIDSON's species, but the former can be distinguished from the latter by its angular primary plications instead of rounded ones.

This species is common in the Jisu Honguer limestone of Jisu Honguer, Outer Mongolia, and was described by GRABAU in detail. It is also very common in the Permian of Himalaya, Salt Range, Indo-China and Timor.

\section{Order Protremata BEECHER, Family Productidae GRAY \\ Genus Waagenoconcha CHaO, Waagenoconcha ef. purdoni (DAVIDSON) \\ Pl. 1 Fig. 5}

1862. Productus purdoni, Datidsox, Q.J.G.S. London, Vol. XVIII, p. 31, Pl. II, Fig. 5.

1884. Productus purdoni, WAagen, Palaeontologia Indica, Ser. XIII, Salt Range Fossils, Vol. I, Productus Limestone Fossils, Pt. 4, p. 705, Pl. LXXIII, Figs. 1-3.

1897. Productus purdoni, Dneswir, Palaeontologia Indica, Ser. XV, Himalayan Fossils, Vol. I, Pt. 4, Permian Fossils of the Productus Shales of Kumaon and Garhwal, p. 21, P1. II, Figs. 1a-c, 2a-c.

1927. Waagenoconcha cf. purdoni, CHAO, Pal. Sin., Ser. B, Vol. V, Fasc. 2, p. 89, Pl. XV, Fig. 4.

1931. Productus (Waagenoconcha) cf. purdoni, GRABav, The Permian of Mongolia, p. 297, Pl. XXIX, Figs. 4a, b.

A single crushed specimen, with essential surface characters of this Permian species of the Jisu Honguer Fauna of Mongolia and of India, was obtained. It is, however, too imperfectly preserved for absolute identification.

\section{Genus Linoproductus CHAO}

\section{Linoproductus cora (d'ORBIGNY) \\ Pl. 1 Figs. 6-9}

1863. Productus cora, DavrDson, Q.J.G.S. London, Vol. XIX, p. 174, Pl. IX, Figs. 22, 23.

1884. Productus corc, W Wagen, Productus Limestone Fossils; Pal. Ind., Ser. XIII, Vol. I, p. 667, PI. LXVI.

1902. Productus cora, TsChennyschew, Mém. du Com. Géol., XVI, No. 2, p. 621, Taf. XXXIII, Figs. 2, 3; Taf. XXXV, Fig. 1; Taf. LIV, Figs. 1-5.

1905. Productus cora, VAUGHaN, Q.J.G.S. London, Vol. LXI, p. 291, PI. XXV, Fig. 4. 
1912. Productus cora, Maxsuy, Mém. Serv. Géol. de l'Indochine, Pal., Vol. I, Fasc. II, p. 95, Pl. XVII, Fig. 9.

1913. Productus cora, MAssuY, Faunas des Calcaires a Productus de l'Indochine, Vol. II, Fas. IV, p. 36, Pl. II, Fig. 14.

1922. Productus cora, HAYSSAKA, Sci. Rep. Töhoku Imp. Univ., Sendai, Second Ser., Vol. VI, No. 1, p. 86, Pl. V, Figs. 3,4 .

1927. Linoproductus lineatus, Chao, Pal. Sin., Ser. B, Vol. V, Fasc. 2, p. 129, Pl. XV, Figs. $25-27$.

1927. Linoproducius cora, Cнао, Ibid., p. 132, Pl. XIII, Figs. 17, 18; PJ. XIV, Figs. 1-4.

1931. Linoproductus cora, Ozaki, Bull. Shanghai Sci. Inst., Vol. I, No. 6, p. 140, Pl. XIII, Fige. $i-5$.

1934. Productus (Linoproductus) cora, Pal. Sin., Ser. B, Vol. VIII, Fasc. 3, p. 42, PI. II, Fig. 16.

This well-known and wide-spread species is represented in our collection by several fragmental specimens including imperfect impressions. These show the normal characteristics of the species.

Concerning the specific circumscription of Linoproductus cora d'ORBIGNY and $P$. lineatus WAAGEN, many investigators have discussed the matter up to this time. In reality the difference between the two species is so negligible that the latter has mostly been designated a synonym or a variety of the former. According to CHAO and GrabaU, d'OrBignY's species may be ancestral to WAAGEN's species.

\author{
Pelecypoda \\ Order Anisomyaria NeuMAYER, Family Aviculidae LAMARCK \\ Genus Pseudomonotis BEYRICH, Subgenus Aviculomonotis GraBaU \\ Pseudomonotis (Aviculomonotis) leazanensis (de VERNEUIL) \\ Pl. 1 Figs. 10. 11.
}

1881. Pseudomonoiis kazanensis, Verneuit, WaAeen, Palaeontologia Indica, Ser. XIII, Salt Range Fossils, Vol. I, Productus Limestone Fossils, p. 281, Pl. XXII, Fig. 3.

1931. Pseudomonotis (Aviculomonolis) kazanensis, GraBaú, The Permian of Mongolia, p. 325, PI. XXXI, Fig. 8.

The specimen is a fragmental mould of the left valve. The apical part, the ears and a part of the lateral margins of the shell are lacking.

The shell is medium sized, gently convex. The preserved length of the valve along the crescence line and the maximum width, are $28 \mathrm{~mm}$ and $25 \mathrm{~mm}$ respectively, but when the apical part and the lateral margins are restored, both the length and the width will be about $5 \mathrm{~mm}$ longer than the above measurements.

In our specimen the surface is marked by seven or eight radiating primary plicae, which 
are strong and sharp, and are separated by somewhat unequal interspaces. The most distantly spaced interval between the crests in the central portion of the shell is about $6 \mathrm{~mm}$ near the base, but the next adjoining interval is $5 \mathrm{~mm}$. The width of the plicae is $1.5 \mathrm{~mm}$ near the base, and their summits are rounded. The finer radiating striae, three or four in number, are intercalated in these interspaces, about $1 \mathrm{~mm}$ apart from each other at the base of the shell, and between them, in some cases, still finer tertiary striae are visible. The primary and the secondary striae are crossed by numerous fine concentric lines of growth.

This species appears to be common in the Permian of U.S.S.R. A single specimen, from the Upper Productus Limestone of the Salt Range of India, was described by WAAGEN. It was also found in the Enteletes bed of the Jisu Honguer Limestone of Jisu Honguer, Mongolia, by MorrIs, and deseribed by GraBAU.

From the above description, the Yuchuan fauna can be correlated with that of the Jisu Honguer limestone of Mongolia. GRABAU has concluded that the latter corresponds in age to the Schwagerina (= Pseudoschuagerina) Stage of Ural. Therefore the Lower Permian geosyncline in the Mongolian district may have extended into Manchuria, because it is highly probable that the Lower Permian complex of Yuchuan was deposited in the same sea basin as the contemporaneous sediments of Jisu Honguer.

It is a remarkable fact that we can't find even a bit of fossil remains of Fusulinid Foraminifera from these two localities. Recently, the author has received many marine fossils from OKADA, which were obtained at the northern part of Dabsnoor, about $500 \mathrm{~km}$ east of Jisu Honguer, Inner Mongolia. After studying these fossils, the author distinguished about 35 genera and 50 species, ${ }^{6)}$ which confirm that this fauna corresponds exactly to that of the Jisu Honguer. The Dabsnoor fauna also contains no Fusulinid remains.

All these data are highly important in suggesting the extension of the Mongolian Geosyncline of Lower Permian age. We can expect in the future the discovery of fossils or sediments of that time in the other localities of the geosynclinal area between Jisu Honguer and Yuchuan.

6) The important species of the Dabsnoor fauna are as follows:

Bryozoa: Geinitzella collumnaris var. tuberosa-sparsigemmata GRABAU

Brachiopoda: Dielasma millepunctatum var. mongolicum $\mathrm{G}_{\mathrm{R} .}$, Spiriferella kailhaviiformis $\mathrm{F}_{\mathrm{RE}}$ Dnicks, Spirifer moosakhailensis Davrdson, Choristites trautscholdi (SwuCrennBerG), Martinia mongolica Grz., M. orbicularis Gemmencano, Camarophoria superstes (Verneuri), C. purdoniformis Gr., Enteletes obesa Gr., Schuchertella frechi Husan, Schellwienella regina Gr., Derbya dupliciseptata $\mathrm{G}_{\mathrm{R} .}$, Linoproductus cora (d'ORBIGNY), Marginifera morrisi CrrAO.

Pelecypoda : Sanguinolites olseni Gr., Pseudomonotis (Aviculomonotis) kazanensis (DE VerreurL) Gastrupoda! Bellerophon jonesianus DE Konisck, Luciella planoconvexa Gr.

Coral: Tetrapora syringoporoides $\mathrm{Y}_{\mathrm{OH}}$ 